\title{
New Method of Visibility Network and Statistical Pattern Network Recognition Usage in Terrain Surfaces
}

\author{
Matej Babič ${ }^{1, *}$, Miłosz Andrzej Huber², Elzbieta Bielecka ${ }^{3}$, Metin Soycan ${ }^{4}$, Wojciech Przegon ${ }^{5}$, Ljubomir Gigovićc \\ Siniša Drobnjak ${ }^{7}$, Dragoljub Sekulović ${ }^{7}$, Ivan Pogarčić ${ }^{8}$, George Miliaresis ${ }^{9}$, Matjaž Mikoš ${ }^{10}$, Marko Komac ${ }^{10}$ \\ 1,* Jožef Stefan Institute, Slovenia \\ ${ }^{2}$ Maria Curie -Sklodowska University, Lublin, Poland \\ ${ }^{3}$ Military University of Technology, Faculty of Civil Engineering and Geodesy, Poland \\ ${ }^{4}$ Yildiz Technical University, Faculty of Civil Engineering, Department of Geomatic Engineering Davutpasa Campus TR-34220 \\ Esenler-Istanbul-Turkey \\ ${ }^{5}$ University of Agriculture in Krakow, Poland \\ ${ }^{6}$ University of Defence, Military Academy, Serbia \\ ${ }^{7}$ Military Geographical Institute, Belgrade, Serbia \\ 8 Juraj Dobrila University of Pula, Croatia \\ ${ }^{9}$ University of Patras, Greece \\ ${ }^{10}$ Faculty of Civil and Geodetic Engineering, University of Ljubljana Slovenia
}

\begin{abstract}
Many problems in the analysis of natural terrain surface shapes and the construction of terrain maps to model them remain unsolved. Almost the whole process of thematic interpretation of aerospace information consists of a step-by-step grouping and further data conversion for the purpose of creating a completely definite, problematically oriented picture of the earth's surface. In this article, we present application of a new method of drawing 3D visibility networks for pattern recognition and its application on terrain surfaces. For the determination of complexity of 3D surface terrain, we use fractal geometry method. We use algorithm for constructing the visibility network to analyse the topological property of networks used in complex terrain surfaces. Terrain models give a fast overview of a landscape and are often fascinating and overwhelmingly beautiful works by artists who invest all their interest and an immense amount of work and know-how, combined with a developed sense of the portrayed landscape, in creating them. At the end, we present modelling of terrain surfaces with topological properties of the visibility network in 3D space.
\end{abstract}

Key words: Network theory, complex pattern recognition, terrain surface analysis, modelling

\section{POVZETEK}

Obstaja mnogo nerešenih problemov s področja analize oblik terenov naravnih površin in izdelavo njihovega modela. Skoraj celoten proces tematske interpretacije letalskih in vesoljskih informacij je sestavljen iz skupine po korakih in nadaljnje pretvorbe podatkov z namenom oblikovanja popolnoma določene, problematično usmerjene slike zemeljske površine. $\mathrm{V}$ tem članku predstavljamo uporabo nove metode konstruiranja 3D omrežij vidljivosti za prepoznavanje vzorcev in njeno uporabo na površinah terena. Za določanje kompleksnosti 3D površine terena uporabljamo metodo fraktalne geometrije. Uporabljamo algoritem omrežja vidljivosti za analizo topoloških lastnosti omrežij, ki se uporabljajo na kompleksnih terenih. Terenski modeli omogočajo hiter pregled pokrajine in so pogosto očarljiva in lepa dela umetnikov, ki vlagajo vse svoje zanimanje in ogromno dela in znanja, skupaj z razvitim občutkom za predstavljene pokrajine pri njihovi ustvarjanju. Na koncu predstavljamo modeli površine terena s topološkimi lastnostmi 3D omrežij vidljivosti.

KLJUČNE BESEDE: Teorija omrežij, razpoznavanje kompleksnih vzorcev, analiza površine terena, modeliranje

Ә Open Access. (C) 2018 Babič M, Huber m.A., Bielecka E, Soycan M, Przegon W, Gigović L, Drobnjak S, Sekulović D, Pogarčić I, Miliaresis G, Mikoš M, Komac M., published by Sciendo. (cc)BY-NC-ND This work is licensed under the Creative Commons Attribution-NonCommercial-NoDerivatives 4.0 License. 


\section{Introduction}

Network theory and graph theory are very useful in Geography. Landscape network models can be a useful tool (procedure) in landscape aesthetic value management and spatial planning processes [1]. Visibility calculations [2] are central to any computer graphics and geoinformation system (GIS) application. Visibility graph analysis [3] is a spatial analysis technique that can also be applied to terrain surface analysis. Existing or newly designed houses, structures, quarters, etc. are considered as peaks, and the connecting roads, engineering networks, transmission lines, etc., are like ribs. The process of creating terrain and landscape models [4] is important in various computer graphics and many visualisation applications. Figure 1 presents a terrain surface. Terrain surfaces [5] represent phenomena that have definite values at each point along the entire range of their extent. The values of an infinite set of points on the entire surface are extracted from a limited set of initial values. They can be based on direct measurements, for example, elevation height values or temperature values for temperature surfaces. The values for the surface between the measurement points are assigned by interpolation. Surfaces can also be mathematically calculated based on other data, for example, surface slopes or exposures, derived from terrain surface data, the surface of distances from bus stops in a city or a surface, showing the concentration of criminal activity or the possibility of strikes.

In problems of transforming the terrain into a project surface, mathematical methods are often used. In modern conditions of designing in real time or object-oriented design, the solution of some problems is eliminated with a geometric approach. This approach is called geometric modelling. More and more popular are the methods of geometric modelling in engineering design through computer modelling, since the solution to the problem acquires a spatial, visual appearance. In the design of the project surface relative to the terrain, a mathematical method is applied to the input data $x, y$, and $z$ coordinates of discrete points of the relief. Transformation of the relief into the project surface requires a high-level engi-

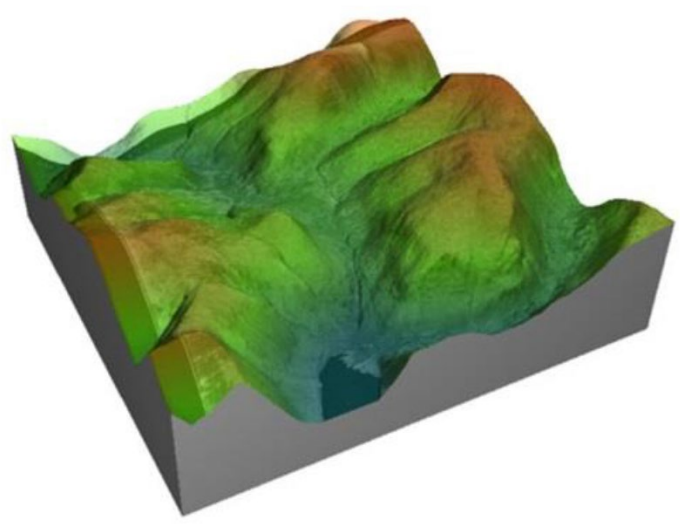

Figure 1: Terrain surface.

neer of the designer of mathematical skills that complicate the design process. Determination and selection of the optimal design surface along the structural relief lines [6] are becoming more and more in demand in the practice of engineering design, as the design takes place in real time and acquires a creative character. In modern systems of engineering design such as Compass, AutoCAD having input data on the topographic surface, it is possible to construct structural relief lines-profile and cross sections, isolines, slope lines, watersheds, and thalwegs [7]. All this is visualised in real time and gives the widest possibilities for analysis to a design engineer even of the middle class.

Consider an inclined line of an arbitrary flat curve, which is the profile or cross section of the relief. Having a number of such profile or cross sections interspersed at a certain distance (Dx, Dy), we can represent the framework model of the relief. The main task of the analysis of the relief is to determine the general slope of the terrain, and on the basis of it the design surface is selected. At the word "geometry", we have cylinders, triangles, hypotenuses, bisectors of corners, "find the area of a figure", slate boards, and breaking chalk from the depths of memory. The problem is that everything that comes to the mind is a language for describing an extremely narrow set of phenomena of the surrounding world. At home, sometimes, they are close to a parallelepiped, but trees - not the cylinders, the mountains are not cones, but the shape of the cloud is incomprehensible with what to compare. If we look closely, in the world around us this school geometry (we will 
call it Euclidean) describes not so much. The scientists asked this question for a long time, but since they did not find a convincing answer, they wrote down these forms as "disordered", "monstrous", and "unexplored". A global breakthrough occurred only in the 1960-1970s, when the French mathematician Benois Mandelbrot invented and developed his theory of fractals [8]. It was a new, fractal geometry, which took for the object of research all that uneven, broken, and rough that surrounds us (that is, almost all). Mandelbrot found his wonderful order in complex forms of nature. Machine learning [9] is a highly specialised field of knowledge that is part of the main sources of technologies and methods used in the fields of large data and the Internet of things that studies and develops algorithms for automated extraction of knowledge from a raw data set, learning software systems based on the data received, generation of predictive and/or prescriptive recommendations, pattern recognition, etc. Statistics [10] is a science that uses many effective methods (including the method of mass observations, the method of groupings, and the method of generalising indicators) for the achievement of accurate results for the study of an object (subject, phenomenon, and process) and structuring them in a form convenient for the subject text, table, graph, and diagram with the subsequent analysis of the received data; the extracted information forms a statistical vision of the situation, the element of which is the object under study. Statistics is a general theoretical science (a complex of scientific disciplines) that studies the quantitative side of qualitatively defined mass socioeconomic phenomena and processes, their composition, distribution, spatial placement, and movement in time, revealing the current interdependencies and patterns in specific conditions of place and time. So, statistics is a branch of practical activity ("statistical accounting") for the collection, processing, analysis, and publication of mass digital data on various phenomena and processes of public life. Modern information systems and technologies include a large number of procedures that model or support data mining process. To the simplest procedures any type of classification quantitative data on given to users criteria, more complex provide analysis scenes, pro- cesses, phenomena for the purpose of selecting objects with given characteristics or properties. Procedures of this type are present not only in analysis problems in aerospace images but also when processing signals in technical systems, in medical diagnostics, biology, sociology, banking business, and other areas of human activity. As you expand sphere of application of geoinformation technologies and complicating procedures, geoinformation modelling procedures for analysis and classification aggregates of data, objects, and structures are very important in the new generation of GISs. For designing any system of thematic analysis classification of information objects and structures, its application requires a specialist knowledge. Research and development methods, algorithms, and systems for solving such tasks on a computer are engaged in a discipline called pattern recognition [11]. Our purpose in the present paper is to investigate different topological properties of visibility graphs in 3D space, which are being viewed as attractive alternatives in terrain surface analysis. The aim of the study is to use a visibility network algorithm for statistical pattern recognition of 3D classification for the prediction of complex terrain surfaces.

\section{Materials and methods}

A new algorithm for the construction of visibility networks in 3D space was presented in the study by Stempien [12]. This algorithm was used to analyse the topological properties of a complex surface (Figure1). In the visibility graph in 3D space, we calculated topological properties of the graph with the programme Pajek [13]. To analyse the topographical property of the terrain surface, we use the construction of the visibility graph in 3D space. Also, the problem in visibility points that we can connect together. In Figure 2, the problem of visibility network in 3D space is presented. Figure 3 presents the 3D surface and Figure 4 solution for constructing visibility graphs in 3D space for Figure 3.

We analysed a set of 22 randomly created terrain surfaces (Appendix 1). For each terrain surface, we constructed visibility graphs in 3D. After that, we calculated topological properties 


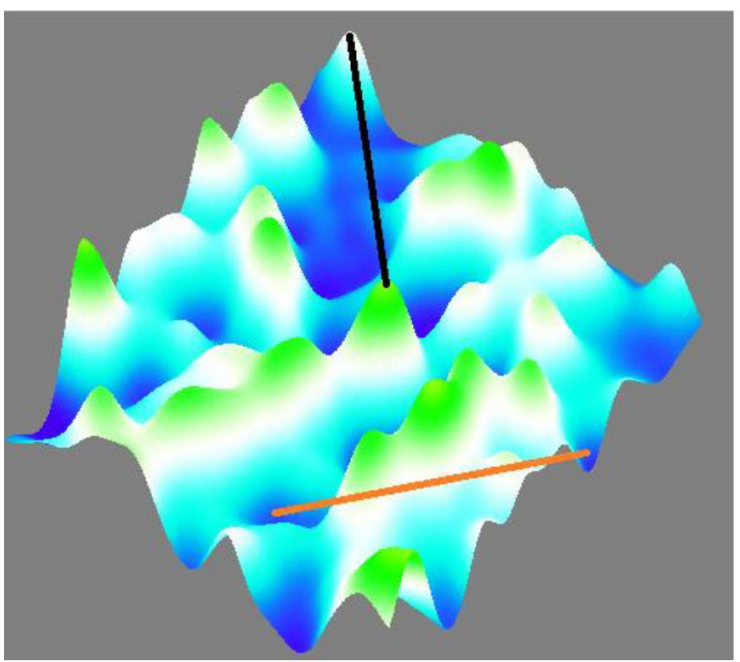

Figure 2: Visibility points (black line) and unrelated points (orange line).

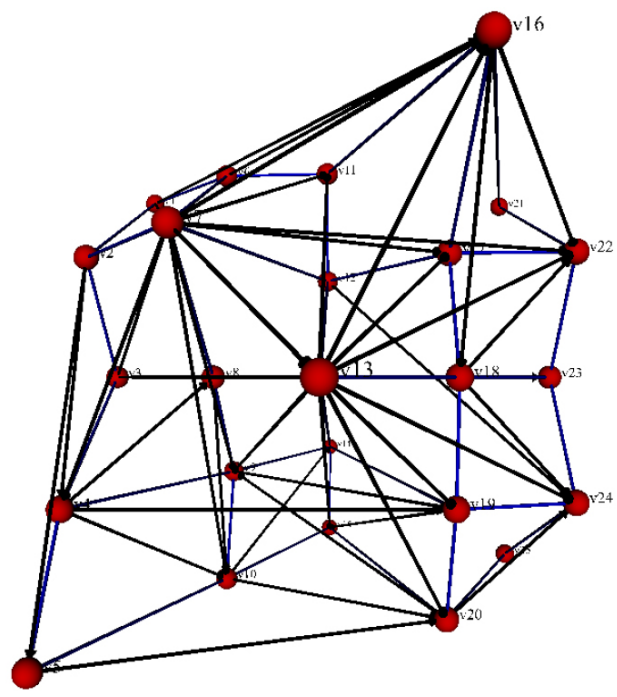

Figure 4: Visibility network in 3D space for Figure 3.

of visibility graph in 3D for each terrain surface. Topological properties can apply to the network as a whole or to individual nodes and edges. Some of the most used topological properties and concepts are \# extremes, \# edges, and \# k-core, All Degree Centralisation, Network Clustering Coefficient, Average Degree, and triadic census type 16-300 of visibility graphs in 3D for each terrain surface. We calculated statistical properties of topological properties of the 3D visibility network of all 22 terrain surfaces. For the determination of complexity of terrain surfaces, we use fractal geometry [14].

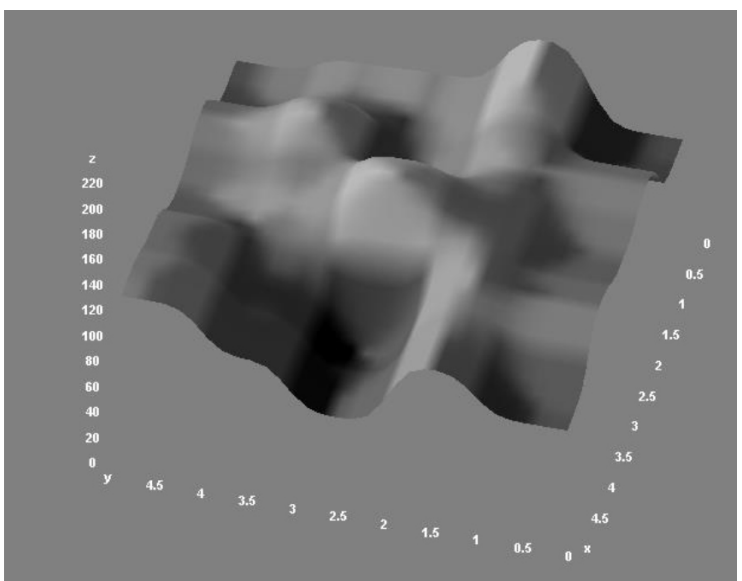

Figure 3: 3D surface.

(a)
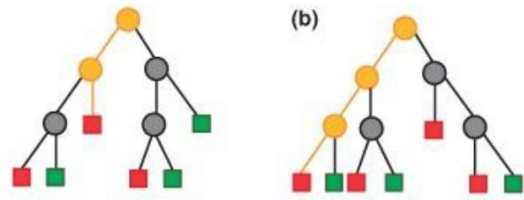

(c)

(d)
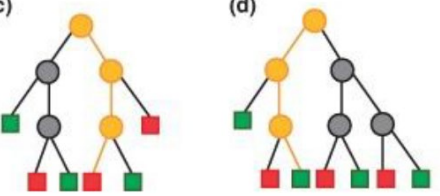

(e)

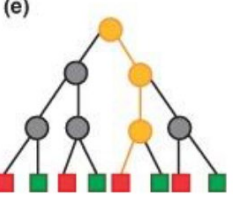

Figure 5: Five illustrative decision trees forming a (very small) random forest for classification.

In fractal geometry, fractal dimension is the key, which determines the complexity of an object. Random forest (RF) [15] is one of the most stunning machine learning algorithms invented by Leo Bryman and Adele Cutler in the last century. He came to us in an "original form" (no heuristics could not substantially improve it) and is one of the few universal algorithms. The universality consists, first, that it is good in many tasks, second, that there are RFs for solving problem classification, regression, clustering, search of anomalies, selection of signs, etc. $\mathrm{RF}$ is a lot of decisive trees. In the task of regression, their answers are averaged, in the task of classification the decision is made by voting for the majority. Figure 5 presents five illustrative decision trees forming a (very small) RF for classification. We use parameters 30 fixed seed for random generator and growth control, not split subsets smaller than 5 . 


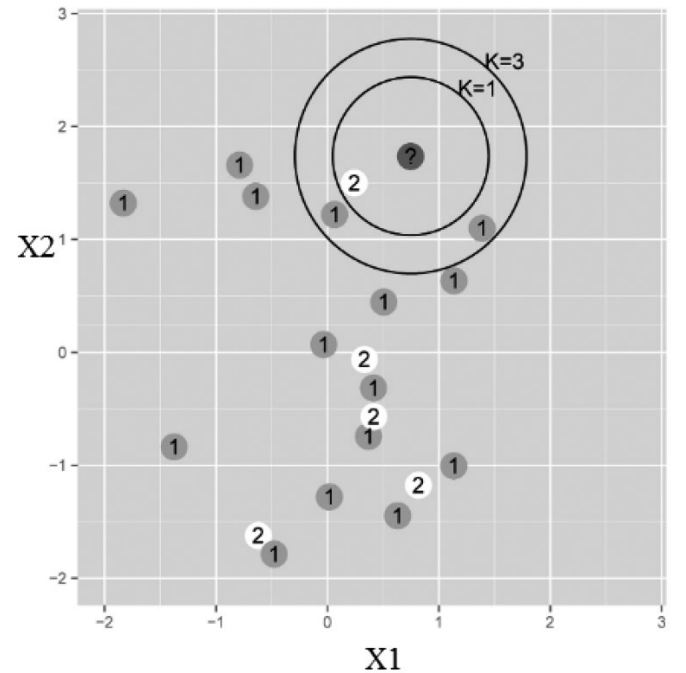

Figure 6: K-nearest neighbours.

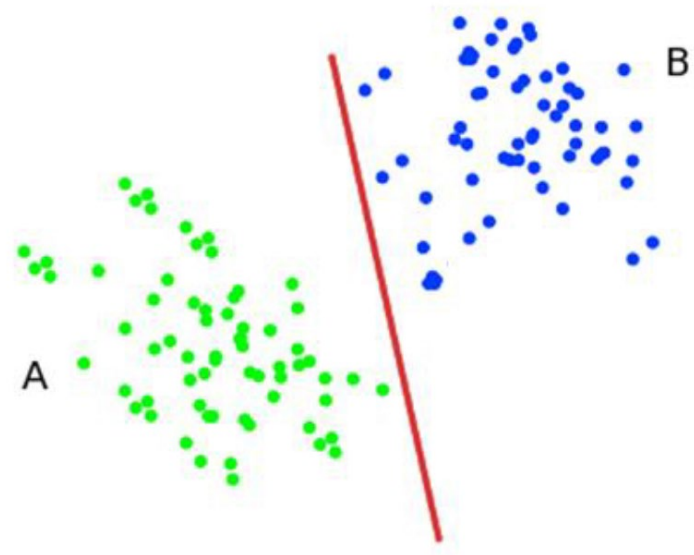

Figure 7: Support vector method.

The K-nearest neighbours model [16] is a method of machine learning, which saves itself as the knowledge of learning. For a given new example, the algorithm finds a given set of learning examples to the nearest, most similar cases and estimates the probability distribution from the relative distribution of these to examples by grade. In the simplest variant of this method, the algorithm is compiled by the new case as the class to which most of the closest neighbours belong. The advanced method takes into account the weighting of the impact of learning examples on the classification of a new case by distance. Figure 6 presents the k-nearest neighbours method. We use parameters 2 neighbours, Chebyshev metric and uniform weight.
The solution of the problem of binary classification using the support vector method [17] consists of finding a linear function that correctly divides the data set into two classes. The problem can be formulated as the search for a function $f(x)$ that takes values less than zero for vectors of one class and greater than zero for vectors of another class. As initial data for the solution of the task, that is, search for the classifying function $\mathrm{f}(\mathrm{x})$, given a training set of space vectors for which they are known to belong to one of the classes. The family of classifying functions can be described in terms of the function $\mathrm{f}(\mathrm{x})$. The hyperplane is defined by the vector $\mathrm{a}$ and the value b, i.e. $\mathrm{f}(\mathrm{x})=\mathrm{a} . \mathrm{x}+\mathrm{b}$. As a result of solving the problem, i.e. constructing an SVM model, a function is found that takes values less than zero for vectors of one class and greater than zero for vectors of another class. For each new object, a negative or positive value determines whether the object belongs to one of the classes. Figure 7 presents the support vector method. We use v-SVM type with regression cost (C) 1.05. Optimisation parameters, we use 100 iteration limit and numerical tolerance 0.002 . We use Kernel $(g \times x \times y+0.15)^{3}$ and $g$ was auto.

\section{Results and discussion}

In Table 1, the topological properties of 3D visibility network are presented. Topological properties present input of predictive models of complexity of terrain surfaces. We mark terrain surfaces from T1 to T22. Column one presents topological property \# extremes, column two presents topological property \# edges, column three presents topological property \# k-core, column four presents topological property All Degree Centralisation, column five presents topological property Network Clustering Coefficient, column six presents topological property Average Degree, and the last column presents topological property triadic census type 16-300. The last column presents complexity of terrain surfaces. Terrain surface T22 has the best topological properties of the 3D visibility network, because T22 has maximal number of edges, Network Clustering Coefficient, and triadic census type 16-300. Terrain surface 
Table 1: Topological properties of the 3D visibility network and fractal dimension.

\begin{tabular}{|c|c|c|c|c|c|c|c|c|}
\hline SP & \# extremes & \# edges & \# k-core & $\begin{array}{c}\text { All Degree } \\
\text { Centralisation }\end{array}$ & $\begin{array}{l}\text { Network } \\
\text { clustering } \\
\text { coefficient }\end{array}$ & $\begin{array}{c}\text { Average } \\
\text { degree }\end{array}$ & $\begin{array}{c}\text { Triadic } \\
\text { census type } \\
16-300\end{array}$ & $\begin{array}{c}\text { Fractal } \\
\text { dimension }\end{array}$ \\
\hline $\mathrm{T} 1$ & 120823 & 3500351 & 16 & 0.00020627 & 0.364 & 6.675 & 4865624 & 2.7365 \\
\hline $\mathrm{T} 2$ & 125787 & 3308776 & 12 & 0.00019998 & 0.364 & 6.311 & 4191425 & 2.668 \\
\hline $\mathrm{T} 3$ & 123943 & 3335861 & 13 & 0.00017608 & 0.371 & 6.363 & 4267175 & 2.6871 \\
\hline $\mathrm{T} 4$ & 124833 & 3355735 & 13 & 0.00017319 & 0.379 & 6.401 & 4353872 & 2.7458 \\
\hline $\mathrm{T} 5$ & 124626 & 3314397 & 12 & 0.00016182 & 0.378 & 6.322 & 4212248 & 2.8065 \\
\hline T6 & 131540 & 3190001 & 12 & 0.00013725 & 0.364 & 6.084 & 3796016 & 2.4956 \\
\hline $\mathrm{T} 7$ & 126962 & 3311163 & 12 & 0.00017518 & 0.373 & 6.316 & 4196282 & 2.1664 \\
\hline $\mathrm{T} 8$ & 130799 & 3173601 & 12 & 0.00018496 & 0.36 & 6.053 & 3741603 & 2.4784 \\
\hline T9 & 123393 & 3355056 & 11 & 0.00016842 & 0.385 & 6.399 & 4256560 & 2.622 \\
\hline $\mathrm{T} 10$ & 126395 & 3386391 & 13 & 0.00015883 & 0.378 & 6.459 & 4483986 & 2.7426 \\
\hline T11 & 124296 & 3315948 & 11 & 0.00026577 & 0.367 & 6.325 & 4207031 & 2.6142 \\
\hline $\mathrm{T} 12$ & 123829 & 3355735 & 13 & 0.00017319 & 0.379 & 6.401 & 4353872 & 2.6982 \\
\hline $\mathrm{T} 13$ & 128143 & 3451450 & 16 & 0.00018446 & 0.352 & 6.583 & 4862060 & 2.6743 \\
\hline $\mathrm{T} 14$ & 122500 & 3685175 & 20 & 0.00027177 & 0.372 & 7.029 & 5877473 & 2.3634 \\
\hline $\mathrm{T} 15$ & 120818 & 3338595 & 11 & 0.00012649 & 0.386 & 6.368 & 4199754 & 2.5155 \\
\hline $\mathrm{T} 16$ & 116812 & 3733624 & 18 & 0.00020016 & 0.364 & 7.121 & 5848517 & 2.5342 \\
\hline $\mathrm{T} 17$ & 133031 & 3178192 & 12 & 0.00013822 & 0.36 & 6.062 & 3774789 & 2.6528 \\
\hline $\mathrm{T} 18$ & 130974 & 3182544 & 15 & 0.00014298 & 0.357 & 6.070 & 3819193 & 2.2996 \\
\hline T19 & 131043 & 3170121 & 13 & 0.00014205 & 0.359 & 6.047 & 3746658 & 2.6427 \\
\hline $\mathrm{T} 20$ & 95090 & 4151533 & 16 & 0.00010784 & 0.387 & 7.918 & 7284078 & 2.1693 \\
\hline $\mathrm{T} 21$ & 106916 & 5653616 & 33 & 0.00021764 & 0.363 & 10.783 & 1764141 & 2.1042 \\
\hline $\mathrm{T} 22$ & 86871 & 5735036 & 19 & 0.00015646 & 0.394 & 10.939 & 1466536 & 2.1332 \\
\hline
\end{tabular}

T17 has a maximal number of extremes of the 3D visibility network. Terrain surface T14 has maximal number of $\mathrm{k}$-core and triadic census type $16-300$ of the 3D visibility network. Terrain surface $\mathrm{T} 11$ has a maximal number of All Degree Centralisation of 3D visibility network. Table 2 presents statistical properties of topological properties of the 3D visibility network of terrain surfaces. We calculated statistical properties such as mean, standard deviation, standard error, median, geometric mean, harmonic mean, variance, skewness, Kurtosis, Fisher's g1, Fisher's g2, coefficient of variation, coefficient of dispersion, communality, area under curve, mean direction (Theta), mean resultant length, circular variance $(\mathrm{V})$, circular standard deviation (v), circular dispersion (Delta), von Mises concentration (Kappa), Phi Pearson's Contingency, Coefficient Tschuprow's T, lambda B, symmetric lambda, Kendall's tau-B, Kendall's tau-C, and gamma of topological properties of the 3D visibility network of terrain surfaces. Terrain surface T21 has maximal \# k-core.

Mostly, we have positive amount in Table 2 unless Skewness and Fisher's g1 for \# extremes, average degree and triadic census type 16-300, kurtosis for average degree and triadic census type 16-300, Kendall's tau-B, Kendall's tau-C and Gamma for \# extremes, All Degree Centralisation, average degree, and triadic census type 16-300. Terrain surface T5 has most complexity. Terrain surface T21 has minimal complexity. This statistic measures the heaviness of the tails of a distribution. The usual reference point 
Table 2: Statistical properties of topological properties of the 3D visibility network.

\begin{tabular}{|c|c|c|c|c|c|c|c|c|c|}
\hline SP & \multicolumn{2}{|c|}{ \# extremes } & \# edge & $\begin{array}{c}\# \\
\mathbf{k} \text {-core }\end{array}$ & \multicolumn{2}{|c|}{$\begin{array}{c}\text { All Degree } \\
\text { Centralisation }\end{array}$} & $\begin{array}{c}\text { Network } \\
\text { clustering } \\
\text { coefficient }\end{array}$ & $\begin{array}{l}\text { Average } \\
\text { degree }\end{array}$ & $\begin{array}{c}\text { Triadic } \\
\text { census type } \\
16-300\end{array}$ \\
\hline Mean & \multicolumn{2}{|c|}{121792} & 3599223 & 14.68 & \multicolumn{2}{|c|}{17586.41} & $3.71 \mathrm{E}+07$ & $5.98 \mathrm{E}+08$ & 4253132 \\
\hline Standard deviation & \multicolumn{2}{|c|}{11531.35} & 714391.3 & 4.86 & \multicolumn{2}{|c|}{4048.007} & 1119925 & $1.64 \mathrm{E}+08$ & 1201353 \\
\hline Standard error & \multicolumn{2}{|c|}{2458.49} & 152308.8 & 1.04 & \multicolumn{2}{|c|}{863.038} & 238768.9 & $3.50 \mathrm{E}+07$ & 256129.4 \\
\hline Median & \multicolumn{2}{|c|}{124461} & 3346826 & 13.00 & \multicolumn{2}{|c|}{17319} & $3.69 \mathrm{E}+07$ & $6.34 \mathrm{E}+08$ & 4209640 \\
\hline Geometric mean & \multicolumn{2}{|c|}{121194} & 3546497 & 14.14 & \multicolumn{2}{|c|}{17168.05} & $3.71 \mathrm{E}+07$ & $5.49 \mathrm{E}+08$ & 4055020 \\
\hline Harmonic mean & \multicolumn{2}{|c|}{120509} & 3505535 & 13.75 & \multicolumn{2}{|c|}{$1.68 \mathrm{E}+04$} & $3.70 \mathrm{E}+07$ & $4.45 E+08$ & 3790200 \\
\hline Variance & \multicolumn{2}{|c|}{$1.3 \mathrm{E}+08$} & $5.10 \mathrm{E}+11$ & 23.66 & \multicolumn{2}{|c|}{$1.64 \mathrm{E}+07$} & $1.25 \mathrm{E}+12$ & $2.69 E+16$ & $1.44 \mathrm{E}+12$ \\
\hline Skewness & \multicolumn{2}{|c|}{-1.89} & 2.409759 & 2.60 & \multicolumn{2}{|c|}{0.8111144} & 0.3436712 & -2.462485 & -0.026658 \\
\hline Kurtosis & \multicolumn{2}{|c|}{5.90} & 7.454659 & 10.23 & 3.5 & 959 & 2.195798 & 8.01742 & 4.719475 \\
\hline Fisher's g1 & -2 & & 2.58979 & 2.79 & 0.8 & 7122 & 0.3693466 & -2.646456 & -0.028649 \\
\hline Fisher's g2 & & & 5.993685 & 9.52 & $0.9^{\prime}$ & 4921 & -0.6906038 & 6.708983 & 2.517122 \\
\hline $\begin{array}{l}\text { Coefficient of } \\
\text { variation }\end{array}$ & & & 0.1984849 & 0.33 & 0.2 & 1782 & 0.03020786 & 0.2743574 & 0.2824632 \\
\hline $\begin{array}{l}\text { Coefficient of } \\
\text { dispersion }\end{array}$ & & & 0.1024648 & 0.21 & 0.1 & 4723 & 0.02531182 & 0.114327 & 0.1701942 \\
\hline Communality & 1.00 & 7201 & 1.000102 & 0.55 & 0.0 & 183 & 0.474759 & 0.964151 & 0.570508 \\
\hline Area under curve & 257 & 577 & $7.46 \mathrm{E}+07$ & 305.50 & 36 & 64.5 & $7.78 \mathrm{E}+08$ & $1.28 \mathrm{E}+10$ & $9.04 \mathrm{E}+07$ \\
\hline $\begin{array}{l}\text { Mean direction } \\
\text { (Theta) }\end{array}$ & 103 & .14 & 178.3926 & 14.67 & 12 & 838 & 157.2197 & 148.077 & 188.3852 \\
\hline $\begin{array}{l}\text { Mean resultant } \\
\text { length }\end{array}$ & & & 0.1746 & 1.00 & & & 0.2903 & 0.3947 & 0.1533 \\
\hline $\begin{array}{c}\text { Circular variance } \\
\text { (V) }\end{array}$ & & & 0.8254 & 0.00 & & & 0.7097 & 0.6053 & 0.8467 \\
\hline $\begin{array}{l}\text { Circular standard } \\
\text { deviation (v) }\end{array}$ & 118 & .11 & 107.0477 & 4.74 & 12 & 001 & 90.1178 & 78.124 & 110.9654 \\
\hline $\begin{array}{l}\text { Circular dispersion } \\
\text { (Delta) }\end{array}$ & & & 12.9282 & 0.01 & & 952 & 5.2048 & 2.7628 & 18.7855 \\
\hline $\begin{array}{l}\text { von Mises } \\
\text { concentration } \\
\text { (Kappa) }\end{array}$ & & & 0.3546 & 146.45 & & & 0.6069 & 0.8603 & 0.3103 \\
\hline Phi & & & 4.4721 & 2.83 & & & 4.4721 & 4.4721 & 4.4721 \\
\hline $\begin{array}{l}\text { Pearson's } \\
\text { contingency } \\
\text { coefficient }\end{array}$ & 0.97 & 0.9759 & 0.94 & & 0.9759 & 0.9759 & 0.975 & & 0.9759 \\
\hline Tschuprow's T & 1 & 0.9879 & 0.79 & & 0.9879 & 0.9879 & 0.987 & & 0.9879 \\
\hline Lambda B & 1 & 0.9524 & 0.38 & & 0.9524 & 0.9524 & 0.952 & & 0.9524 \\
\hline Symmetric lambda & & & 0.9756 & 0.65 & & & 0.9756 & 0.9756 & 0.9756 \\
\hline Kendall's tau-B & -0 & & 0.2338 & 0.28 & & 165 & 0.026 & -0.1126 & -0.1558 \\
\hline Kendall's tau-C & -0 & & 0.2338 & 0.28 & & 165 & 0.026 & -0.1126 & -0.1558 \\
\hline Gamma & -0 & & 0.2348 & 0.32 & & 174 & 0.0261 & -0.113 & -0.1565 \\
\hline
\end{tabular}




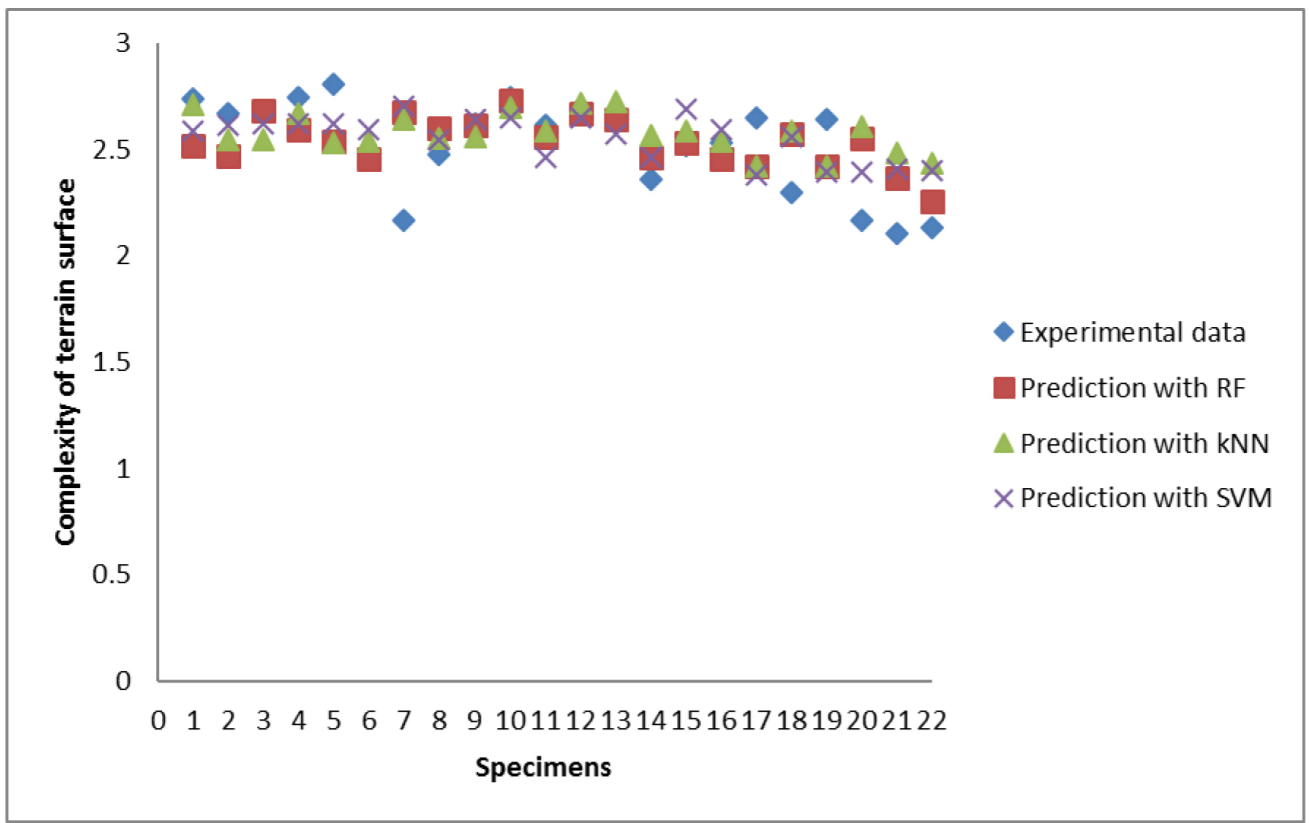

Figure 8: The calculated and predicted surface terrain complexity.

in kurtosis is the normal distribution. If this kurtosis statistic equals three and the skewness is zero, the distribution is normal. Also, we found positive significance between Kurtosis and topological properties of visibility graphs in 3D space of terrain surface. Pearson's contingency coefficient is a measure of association independent of sample size. It ranges between 0 (no relationship) and 1 (perfect relationship). For any particular table, the maximum possible depends on the size of the table (a $2 \times 2$ table has a maximum of 0.707), and so it should only be used to compare tables with the same dimensions. Also, in our result mostly topological properties have Pearson's contingency coefficient 0.97 . Tschuprow's $\mathrm{T}$ is a measure of association independent of sample size. This statistic is a modification of the Phi statistic so that it is appropriate for larger than $2 \times 2$ tables. T ranges between 0 (no relationship) and 1 (perfect relationship), but 1 is only attainable for square tables. In our result, mostly topological properties have Tschuprow's T $=0.98$.

Calculated and predicted data are presented in Table 3. The RF model presents a $6.28 \%$ deviation from the measured data. The k-nearest neighbours model presents a $6.88 \%$ deviation from the measured data. The support vector machine model presents a $6.82 \%$ deviation from the measured data. The calculated and
Table 3: Calculated and predicted data.

\begin{tabular}{ccccc} 
S & ED & P RF & kNN & P SVM \\
\hline T1 & 2.7365 & 2.522 & 2.710 & 2.589 \\
\hline T2 & 2.668 & 2.470 & 2.545 & 2.617 \\
\hline T3 & 2.6871 & 2.683 & 2.545 & 2.625 \\
\hline T4 & 2.7458 & 2.592 & 2.673 & 2.621 \\
\hline T5 & 2.8065 & 2.538 & 2.530 & 2.619 \\
\hline T6 & 2.4956 & 2.460 & 2.537 & 2.596 \\
\hline T7 & 2.1664 & 2.678 & 2.645 & 2.705 \\
\hline T8 & 2.4784 & 2.601 & 2.552 & 2.546 \\
\hline T9 & 2.6220 & 2.612 & 2.558 & 2.646 \\
\hline T10 & 2.7426 & 2.730 & 2.697 & 2.650 \\
\hline T11 & 2.6142 & 2.563 & 2.590 & 2.462 \\
\hline T12 & 2.6982 & 2.668 & 2.721 & 2.649 \\
\hline T13 & 2.6743 & 2.644 & 2.722 & 2.573 \\
\hline T14 & 2.3634 & 2.463 & 2.564 & 2.462 \\
\hline T15 & 2.5155 & 2.535 & 2.590 & 2.694 \\
\hline T16 & 2.5342 & 2.460 & 2.537 & 2.596 \\
\hline T17 & 2.6528 & 2.425 & 2.422 & 2.384 \\
\hline T18 & 2.2996 & 2.572 & 2.587 & 2.563 \\
\hline T19 & 2.6427 & 2.425 & 2.422 & 2.396 \\
\hline T20 & 2.1693 & 2.554 & 2.610 & 2.396 \\
\hline T21 & 2.1042 & 2.366 & 2.481 & 2.407 \\
\hline T22 & 2.1332 & 2.258 & 2.439 & 2.400 \\
\hline
\end{tabular}


predicted surface terrain complexity is shown in the graph in Figure 8.

\section{Conclusions}

The visibility graph problem itself has long been studied in computational geometry and has been applied to various areas. Finally, in this work the visibility network in 3D space, which contains more information than the visibility graph, has been used to analyse the terrain surfaces. Furthermore, we used the new method of construction of the visibility graphs in 3D space to describe the different terrain surfaces for possible further applications in studies of temporal and spatial landscape and/or terrain changes and evolution [18]. The main findings can be summarised as follows:

- We describe the different terrain surfaces by using the topological properties of the visibility graphs in 3D space.

- We present statistical properties of topological properties of the 3D visibility network.

- We use method of machine learning to predict complexity of terrain surfaces.

- With topological properties of 3D visibility network of terrain surface, we model complexity of terrain surface.

- With statistical statistical properties of topological properties of 3D visibility network of terrain surface, we can better analyse and understand complexity of terrain surfaces.

- With statistical properties of 3D visibility network of terrain surface, we can better understand structure of terrain surfaces.

- Terrain surface with minimum complexity has maximal \#k-core.

Possible further testing of the proposed method in the field of landscape/terrain morphology would be:

- Description of temporal changes resp. development of a landscape/terrain using temporal changes in visibility graphs produced on multitemporal LiDAR data [19].

- Application in LiDAR derived high-resolution topography for landform recognition and analysis [20].

- Comparison of visibility graphs with other techniques for analysing terrain texture [21] or landform recognition, such as for landslides [22].

\section{References}

[1] Kowalczyk, A.M. (2015): The use of scale-free networks theory in modeling landscape aesthetic value networks in urban areas. Geodetski vestnik, 59(1), pp. 135-152.

[2] Ben-Moshe, B., Hall-Holt, O., Katz, M.J., Mitchell, J.S.B. (2004): Computing the visibility graph of points within a polygon. SCG'04 Proc. of the $20^{\text {th }}$ Annual Symposium on Computational Geometry: Brooklyn, New York, USA; pp. 27-35.

[3] Overmars, M.H., Welzl, E. (1998): New methods for constructing visibility graphs. In: Proc. 4th Annu. ACM Symp. Computational Geometry. Urbana: Illinois; pp. 164-171.

[4] Stempien, D.C. (2002): Terrain models as battlefield visualization training tools. In: Military Intelligence Professional Bulletin. 28(4). Huachuca City. Arizona; pp. 33-35.

[5] Wilson, J.P., Gallant, J.C. (2000): Digital Terrain Analysis. In: Wilson. J.P., Gallant, J.C. (ed.). Terrain Analysis: Principles and Applications, Chapter 1. New York: Wiley; pp. 1-27.

[6] Haitov, B.U. (2014a): Geometric modeling of the relief for the problems of choosing the optimal design surface and water disposal//Young scientist: Monthly scientific journal. - Kazan, 4(63), pp. 292-194.

[7] Haitov, B.U. (2014b): On the construction of structural relief lines. Young scientist: Monthly scientific journal. - Kazan, 4(63), pp. 289-291.

[8] Boeing, G. (2016): Visual Analysis of Nonlinear Dynamical Systems: Chaos, Fractals, Self-Similarity and the Limits of Prediction. Systems, 4(4), pp. 37-54.

[9] Bridge, J.P., Holden, S.B., Paulson, L.C. (2014): Machine learning for first-order theorem proving. Journal of automated reasoning, 53(2), pp. 141-172.

[10] Marjetič, A., Kregar, K. (2016): Definition of appropriate geodetic datum using robust statistical. Geodetski vestnik, 60(2), pp. 212-226.

[11] Bishop, C.M. (2006): Pattern Recognition and Machine Learning. New York: Springer-Verlag, 738 p.

[12] Babič, M. (2014): Analiza kaljenih materialov s pomočjo fraktalne geometrije. Ph. D. Thesis. Maribor: University of Maribor 2014; 167 p.

[13] De Wouter, N., Mrvar, A., Batagelj, V. (2005): Exploratory Social Network Analysis with Pajek. New York: Cambridge University Press; 334 p. 
[14] Babič, M., Kokol, P., Guid, N., Panjan, P. (2014): A new method for estimating the Hurst exponent $\mathrm{H}$ for 3D objects = Nova metoda za ocenjevanje Hurstovega eksponenta H za 3D-objekte. Materiali in tehnologije, 48(2), pp. 203-208.

[15] Lewoniewski, W., Węcel, K., Abramowicz, W. (2016): Quality and Importance of Wikipedia Articles in Different Languages. Information and Software Technologies. ICIST 2016. Communications in Computer and Information Science, 639, pp. 613-624.

[16] Malkov, Y., Ponomarenko, A., Krylov, V., Logvinov, A. (2014): Approximate nearest neighbor algorithm based on navigable small world graphs. Information Systems, 45, pp. 61-68.

[17] Wenzel, F., Galy-Fajou, T., Deutsch, M., Kloft, M. (2017): Bayesian Nonlinear Support Vector Machines for Big Data (PDF). Machine Learning and Knowledge Discovery in Databases (ECML PKDD). Archived (PDF) from the original on 2017-08-30.

[18] Roering, J.J., Mackey, B.H., Marshall, J.A., Sweeney, K.E., Deligne, N.I., Booth, A.M., Handwerger, A.L., Cerovski-Darriau, C. (2013): "You are HERE”: Connecting the dots with airborne lidar for geomorphic fieldwork. Geomorphology, 200, pp. 172-183.
[19] Eitel, J.U.H., Höfle, B., Vierling, L.A. Abellán, A., Asner, G.P., Deems, J.S., Glennie, C.L., Joerg, P.C., LeWinter A.L., Magney, T.S., Mandlburger, G., Morton, D.C., Müller, J., Vierling, K.T. (2016): Beyond 3-D: The new spectrum of lidar applications for earth and ecological sciences. Remote Sensing of Environment, 186, pp. 372-392.

[20] Lo Ren, G., Fuller, I.C., Sofia, G., Tarolli, P. (2018): High-resolution mapping of Manawatu palaeochannels. New Zealand Geographer, 74(2), pp.77-91.

[21] Tasse, F.P., Gain, J., Marais, P. (2012): Enhanced Texture-Based Terrain Synthesis on Graphics Hardware. Computer Graphics Forum, 31(6), pp. 1959-1972.

[22] Booth, A.M., Roewring, J.J., Perron, J.T. (2009): Automated landslide mapping using spectral analysis and high-resolution topographic data: Puget Sound lowlands, Washington, and Portland Hills, Oregon. Geomorphology, 109, pp.132-147. 


\section{Appendix 1}
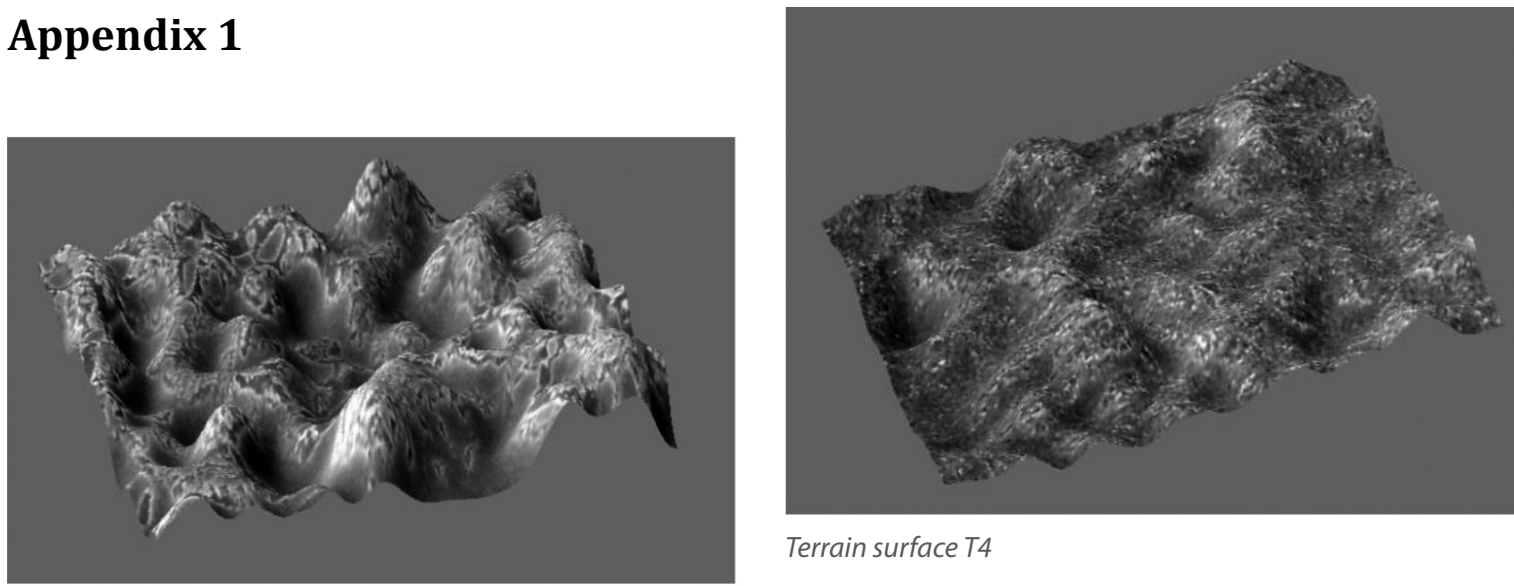

Terrain surface T4

Terrain surface $T 1$
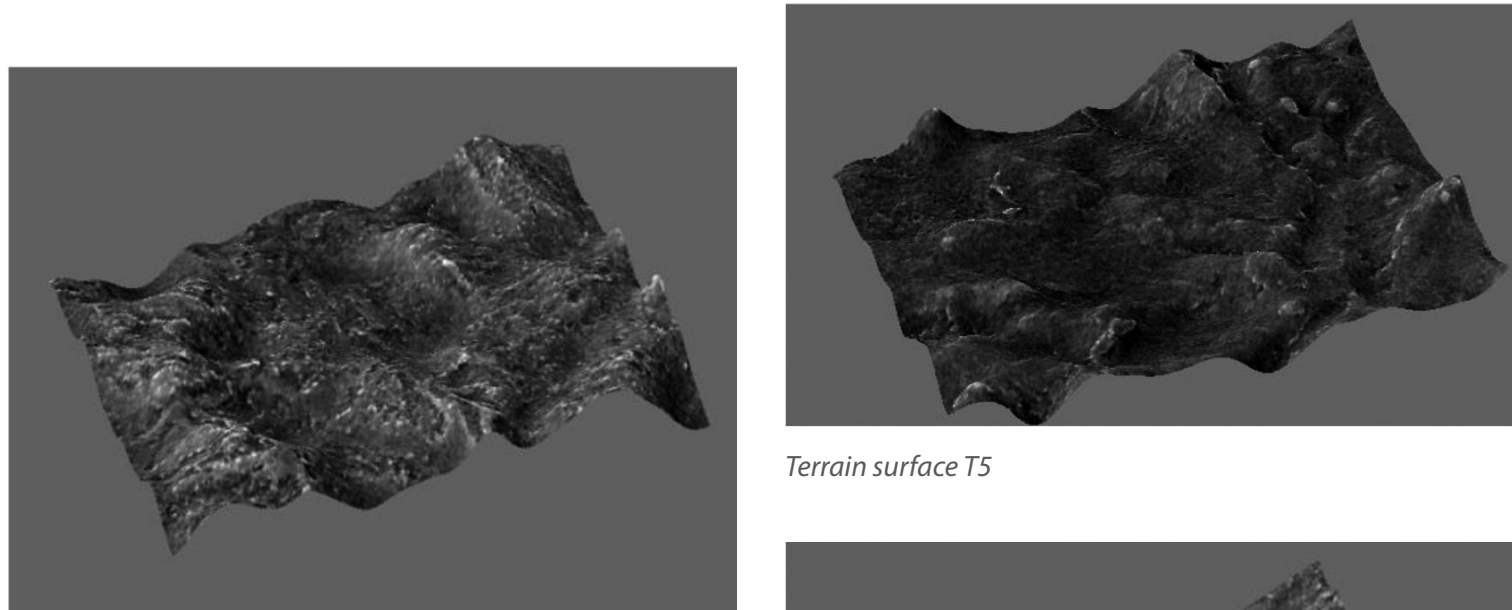

Terrain surface $T 5$

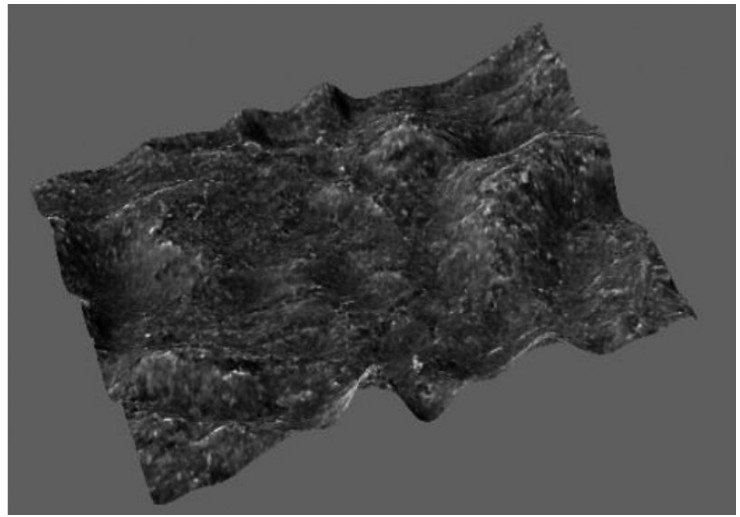

Terrain surface T6

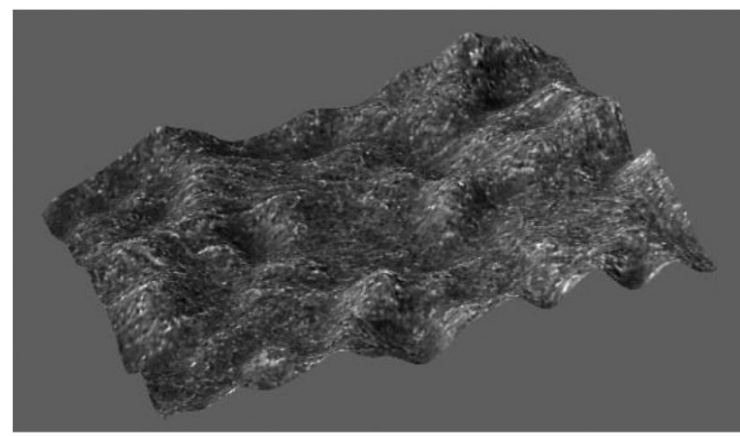

Terrain surface T7 


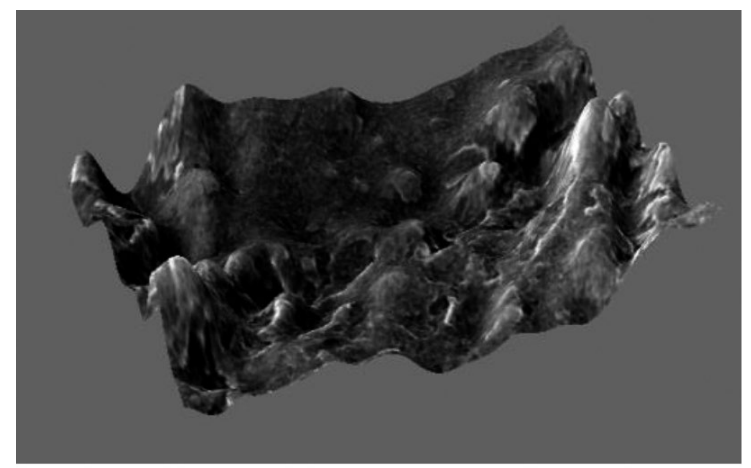

Terrain surface T8

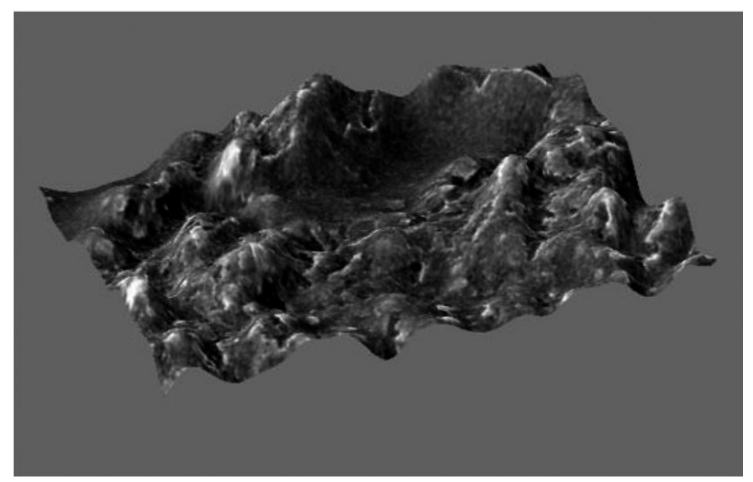

Terrain surface $T 9$

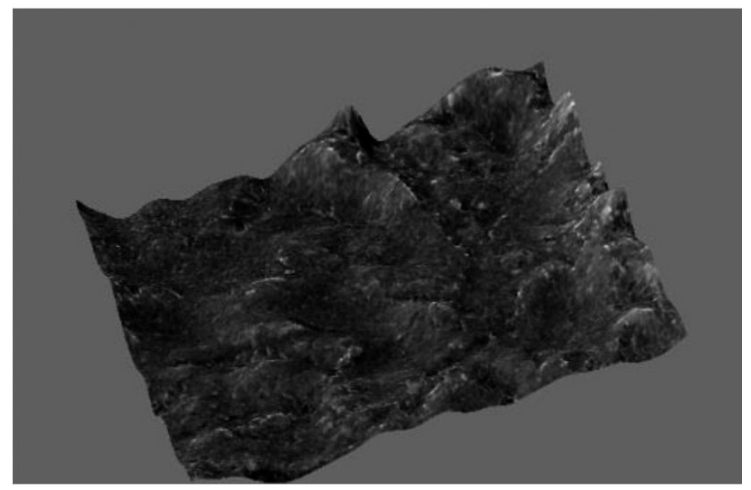

Terrain surface T10

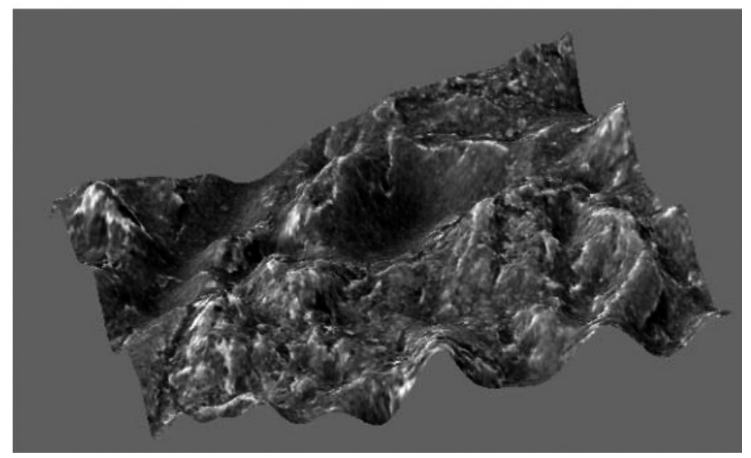

Terrain surface T11

RMZ-M\&G | 2019 | Vol. $66 \mid$ pp. 013-026

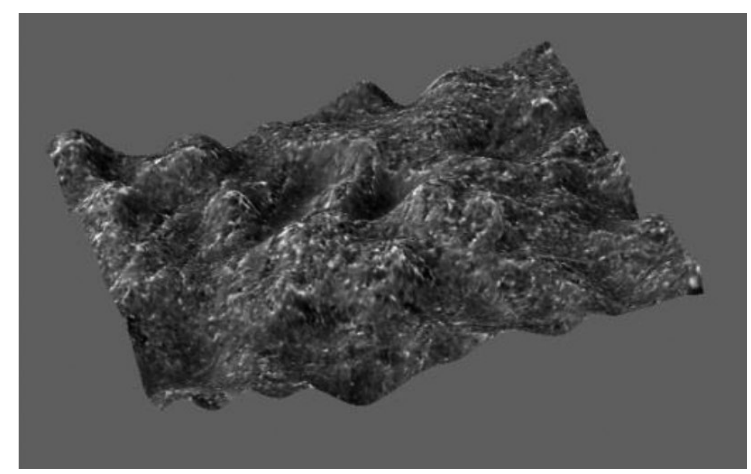

Terrain surface T12

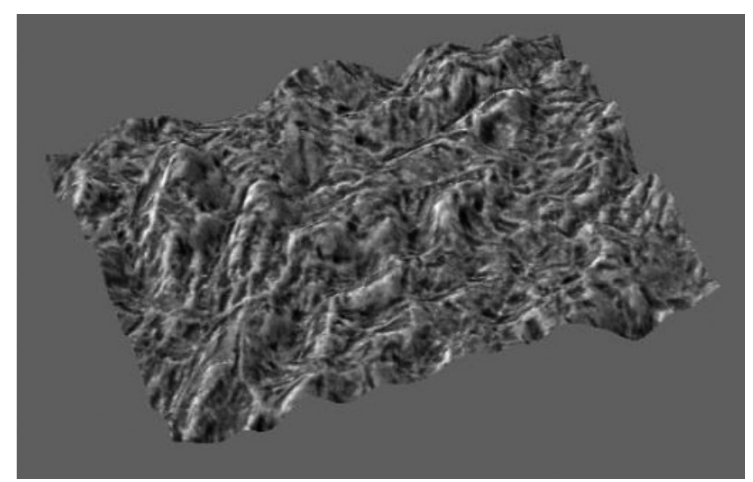

Terrain surface T13

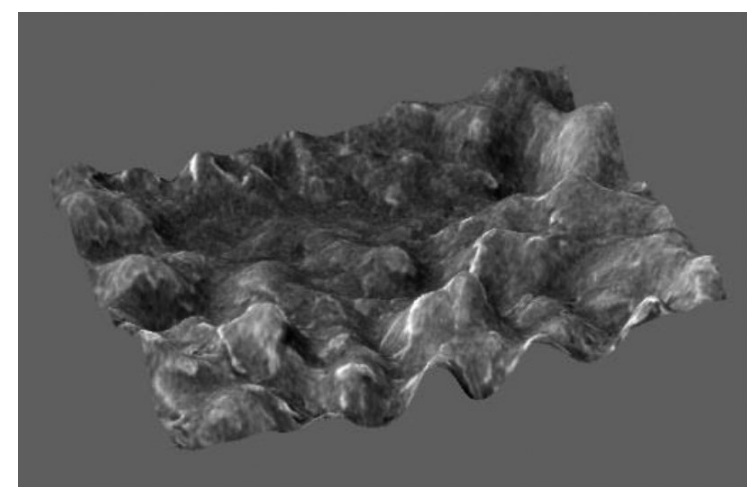

Terrain surface T14

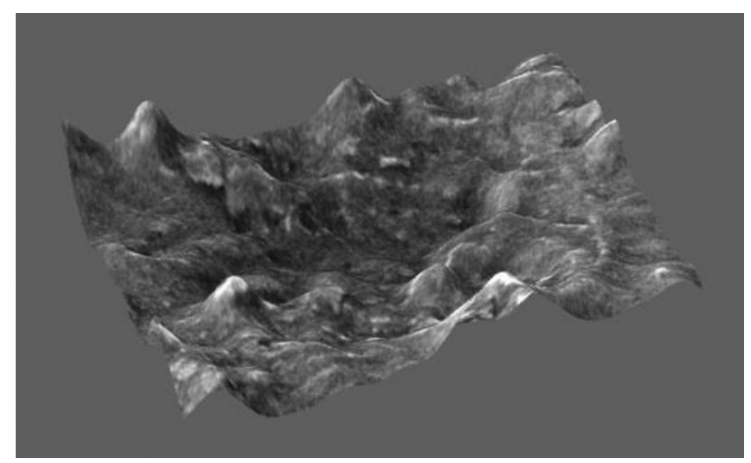

Terrain surface T15

Babič M, Huber m.A., Bielecka E, Soycan M, Przegon W, Gigović L, Drobnjak S, Sekulović D, Pogarčić l, Miliaresis G, Mikoš M, Komac M. 


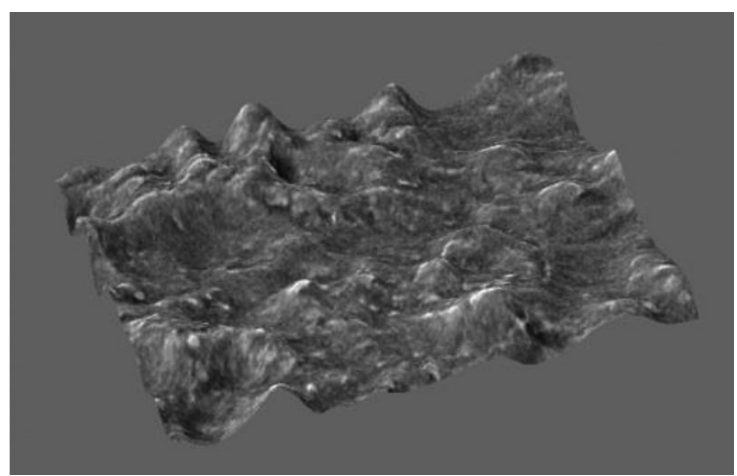

Terrain surface T16

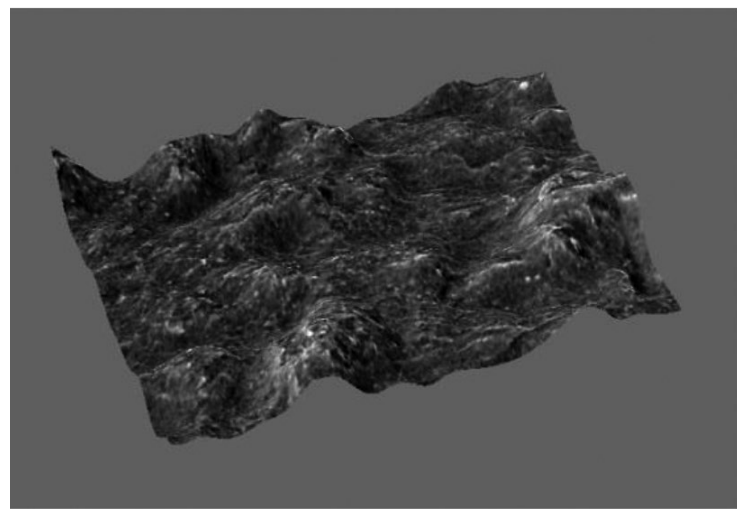

Terrain surface T17

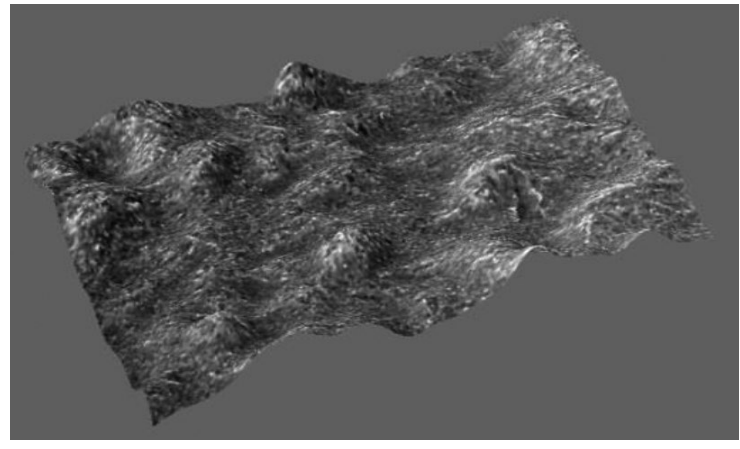

Terrain surface T18

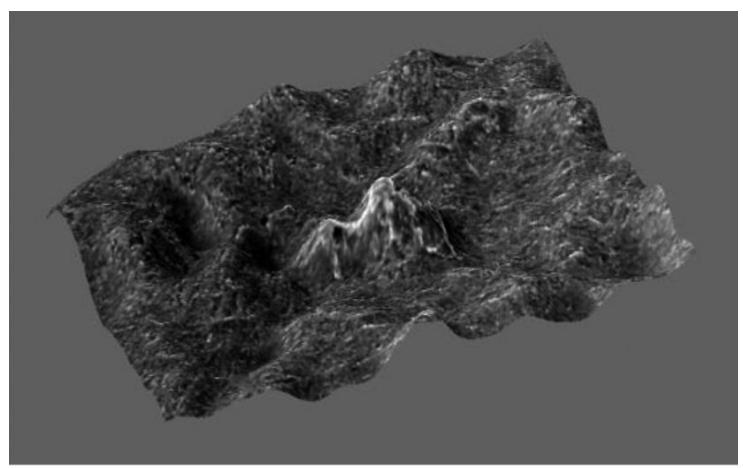

Terrain surface T19

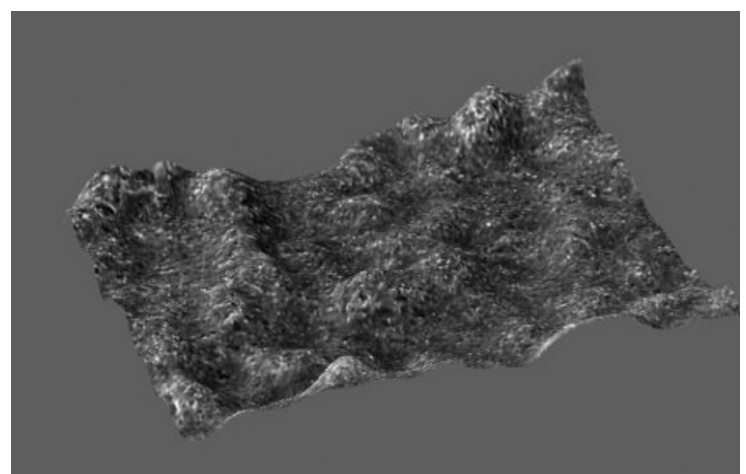

Terrain surface T20

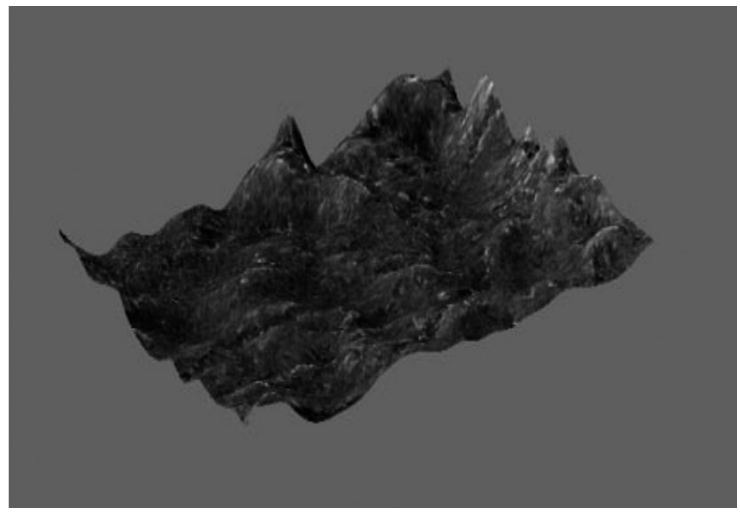

Terrain surface $T 21$

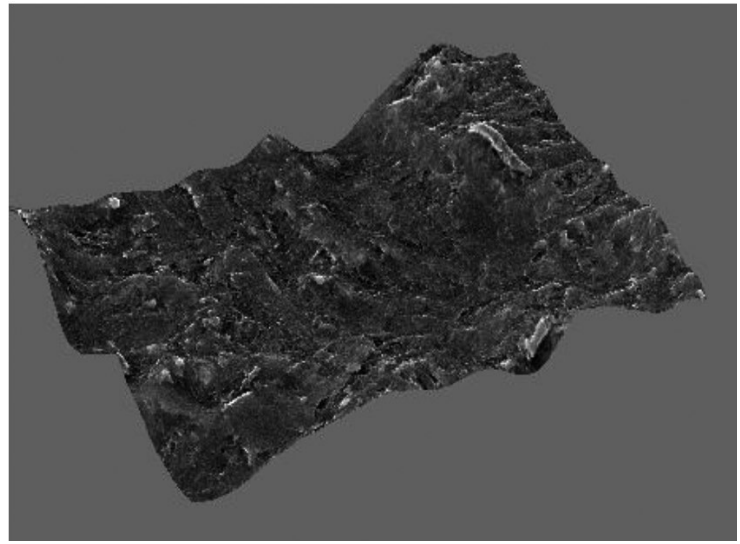

Terrain surface T22 